\title{
Prediction of the functional outcome of cerebral ischemic supratentorial stroke acute period on the basis of spectral analysis of the brain bioelectrical activity
}

\author{
A. A. Kuznietsov \\ Zaporizhzhia State Medical University, Ukraine
}

Key words: brain infarction, electroencephalography, prognosis.

\section{Zaporozhye} medical journal 2018; 20 (3), 324-329 DOI: 10.14739/2310-1210 2018.3.132127

E-mail: titus3.05@gmail.com
The purpose of this study was to determine the most informative parameters of the brain bioelectrical activity spectral analysis for the functional outcome of cerebral ischemic supratentorial stroke (CISS) acute period prediction.

Materials and methods. Prospective, cohort and comparative study was conducted among 103 patients in CISS acute period (61 men and 42 women, mean age was $67.7 \pm 0.8$ years). Electroencephalographic study was conducted on the $2^{\text {nd }}-3^{\text {rd }}$ day of the disease with the use of 19-channel electroencephalographic scanner. The values of absolute spectral rhythm power of delta (0.5-4.0 Hz), theta (4-8 Hz), alpha (8-13 Hz), beta (13-35 Hz), theta1 (4-6 Hz), theta2 (6-8 Hz), alpha1 (8-10 Hz), alpha2 (10-13 $\mathrm{Hz})$, beta1 $(13-25 \mathrm{~Hz})$ and beta2 $(25-35 \mathrm{~Hz})$ bands in the affected hemisphere $(\mathrm{AH})$ and intact hemisphere $(\mathrm{IH})$ were determined. The relative spectral rhythm power (RSRP), fronto-occipital rhythm gradient (FORG) and the severity of interhemispheric rhythm asymmetry (IHRA) were calculated. The functional outcome of the disease acute period was assessed on the 21st day on the basis of the modified Rankin Scale (mRS), while the value of $m R S$ score $>3$ was considered as an unfavourable functional outcome.

Results. Unfavourable functional outcome of the CISS acute period was registered in 46 (44.6\%) patients. In accordance with the data of multivariate regression analysis it was determined that RSRP of delta band in the $\mathrm{IH}(\mathrm{OR} 95 \% \mathrm{Cl}=1.31(1.13-1.52)$, $\mathrm{P}=0.0004)$, FORG of alpha band in the $\mathrm{AH}(\mathrm{OR} 95 \% \mathrm{Cl}=29.07(1.86-455.15), \mathrm{P}=0.0224)$ and IHRA of alpha band (OR $95 \%$ $\mathrm{Cl}=0.01(0.0001-0.80), \mathrm{P}=0.0402)$ were independently associated with functional outcome of the CISS acute period. The RSRP of delta band in the $\mathrm{IH}>18.4 \%(\mathrm{Se}=87.0 \%, \mathrm{Sp}=87.7 \%, \mathrm{AUC} 95 \% \mathrm{Cl}=0.94(0.87-0.98), \mathrm{P}<0.0001)$, FORG of alpha band in the $\mathrm{AH}>-0.066(\mathrm{Se}=67.4 \%, \mathrm{Sp}=70.0 \%$, AUC $95 \% \mathrm{Cl}=0.74(0.65-0.82), \mathrm{P}<0.0001)$ and IHRA alpha band $\leq-0.066$ $(\mathrm{Se}=60.9 \%, \mathrm{Sp}=70.2 \% \mathrm{AUC} 95 \% \mathrm{Cl}=0.66(0.56-0.75), \mathrm{P}<0,0039)$ were the optimal cut-off values as for the unfavourable functional prognosis of CISS acute period.

Conclusions. The RSRP of delta band in the IH, FORG of alpha band in the AH and the IHRA of alpha band are the most informative parameters of the brain bioelectrical activity spectral analysis for the prediction of the functional outcome of cerebral ischemic supratentorial stroke acute period.

\section{Ключові слова:} інфаркт мозку, електроенцефалографія,

прогноз.

\section{Запорізький} медичний журнал. - 2018. T. 20, № 3(108). C. 324-329

\section{Прогнозування функціонального виходу гострого періоду мозкового ішемічного супратенторіального інсульту на підставі спектрального аналізу біоелектричної активності головного мозку}

\section{А. А. Кузнєцов}

Мета роботи - визначити найбільш інформативні параметри спектрального аналізу біоелектричної активності головного мозку для прогнозування функціонального виходу гострого періоду мозкового ішемічного супратенторіального інсульту (MICl).

Матеріали та методи. Виконали проспективне, когортне, порівняльне дослідження 103 пацієнтів у гострому періоді MICl (61 чоловік і 42 жінки, середній вік - 67,7 \pm 0,8 року). Рівень неврологічного дефіциту оцінювали за National Institute of Health Stroke Scale. Електроенцесралографічне дослідження виконали на 2-3 добу захворювання. Окремо для ураженої півкулі (УП) і неураженої півкулі (НП) встановлювали значення абсолютної спектральної потужності, відносної спектральної потужності ритмів (ВСПР) дельта (0,5-4 Гц), тета (4-8 Гц), альфра (8-13 Гц), бета (13-35 Гц) діапазонів, тета1 (4-6 Гц), тета2 (6-8 Гц), альфра1 (8-10 Гц), альфа2 (10-13 Гц), бета1 (13-25Гц) та бета2 (25-35 Гц) піддіапазонів, а також лобно-потиличні градієнти (ЛПГР) і вираженість міжпівкульної асиметрії ритмів (МПАР). Функціональний вихід гострого періоду МІCI оцінювали на 21 добу захворювання за модифікованою шкалою Ренкіна (мШР), при цьому несприятливим функціональним наслідком вважали значення >3 бали за мШР.

Результати. Несприятливий функціональний вихід зареєстрували у 46 (44,6 \%) пацієнтів. На підставі мультиваріантного логістичного регресійного аналізу визначено параметри спектрального аналізу електроенцефалографічного патерну, які незалежно асоційовані з функціональним виходом гострого періоду МІСІ: ВCПР дельта-діапазону IП (ВШ 95 \% ДI = 1,31 (1,13-1,52), p = 0,0004), ЛПГР альфа-діапазону УП (ВШ $95 \%$ ДI = 29,07 (1,86-455,15), p = 0,0224) та МПАР альфра-діапазону (ВШ $95 \% \mathrm{Zl}=0,01(0,0001-0,80), p=0,0402)$, при цьому оптимальними точками відсікання значень названих показників для верифікації функціонального прогнозу є ВCПР дельта-діапазону IП > 18,4 \% (Se = 87,0\%, Sp = 87,7 \%, AUC $95 \% \mathrm{Zl}=0,94$ (0,87-0,98), p < 0,0001), ЛПГР альфа-діапазону УП >-0,066 (Se = 67,4 \%, Sp = 70,0\%; AUC $95 \%$ Дl = 0,74 $(0,65-0,82), p<0,0001)$ та МПАР альфа-діапазону $\leq-0,066$ (Se $=60,9 \%$, Sp $=70,2 \%$, AUC $95 \%$ ДI = 0,66 $(0,56-0,75)$, $p<0,0039)$.

Висновки. Найбільш інформативними параметрами спектрального аналізу біоелектричної активності головного мозку для визначення функціонального прогнозу завершення гострого періоду $\mathrm{MICl} є$ відносна спектральна потужність ритмів дельта-діапазону інтактної півкулі, лобно-потиличний градієнт ритмів альфра-діапазону ураженої півкулі та міжпівкульна асиметрія ритмів альфа-діапазону. 


\section{Прогнозирование функционального исхода острого периода мозгового ишемического супратенториального инсульта на основании спектра^ьного анализа биоэлектрической активности головного мозга}

\begin{abstract}
А. А. Кузнецов
Цель работы - определить наиболее инфрормативные параметры спектрального анализа биоэлектрической активности головного мозга для прогнозирования функционального исхода острого периода мозгового ишемического супратенториального инсульта (МИСИ).

Материалы и методы. Проведено проспективное, когортное, сравнительное исследование 103 пациентов в остром периоде МИСИ (61 мужчина и 42 женщины, средний возраст - 67,7 \pm 0,8 года). Уровень неврологического дефицита оценивали по National Institute of Health Stroke Scale. Электроэнцесралографическое исследование проводили на 2-3 сутки заболевания. Отдельно для пораженного полушария (ПП) и непораженного полушария (НП) определяли значения абсолютной спектральной мощности, относительной спектральной мощности ритмов (ОСМР) дельта (0,5-4 Гц), тета (4-8 Гц), альфа (8-13 Гц), бета (13-35 Гц) диапазонов, тета1 (4-6 Гц), тета2 (6-8 Гц), альфа1 (8-10 Гц), альфа2 (10-13 Гц), бета1 (13-25 Гц) и бета2 (25-35 Гц) поддиапазонов, а также лобно-затылочные градиенты (Л3ГР) и выраженность межполушарной асимметрии ритмов (МПАР). Функциональный исход острого периода МИСИ оценивали на 21 сутки заболевания по модифицированной шкале Рэнкина (мШР), при этом в качестве неблагоприятного функционального исхода рассматривали значение >3 балла по мШР.
\end{abstract}

Результаты. Относительно неблагоприятный функциональный исход зарегистрирован у 46 (44,6 \%) пациентов. На основании мультивариантного логистического регрессионного анализа определили параметры спектрального анализа ЭЭГ-паттерна, которые независимо ассоциированы с функциональным исходом острого периода МИСИ: ОСМР дельта-диапазона ИП (ОШ 95 \% ДИ = 1,31 (1,13-1.52), p = 0,0004), ЛЗГР альфа-диапазона ПП (ОШ 95 \% ДИ = 29,07 (1,86-455,15), p = 0,0224) и МПАР альфра-диапазона (ОШ $95 \%$ ДИ = 0,01 $(0,0001-0,80), p=0,0402)$, при этом оптимальными точками отсечения значений указанных показателей для верификации функционального прогноза выступают ОСМР дельта-диапазона ИП >18,4\% (Se = 87,0 \%, Sp = 87,7 \%, AUC $95 \%$ ДИ = 0,94 (0,87-0,98), p < 0,0001), ЛЗГР альфра-диапазона ПП >-0,066 $(\mathrm{Se}=67,4 \%, \mathrm{Sp}=70,0 \%$; AUC $95 \%$ ДИ = 0,74 (0,65-0,82), p < 0,0001) и MПAP альфа-диапазона $\leq-0,066$ (Se $=60,9 \%$, $\mathrm{Sp}=70,2 \%$ AUC $95 \%$ ДИ $=0,66(0,56-0,75), \mathrm{p}<0,0039)$.

Выводы. Наиболее информативные параметры спектрального анализа биоэлектрической активности головного мозга для определения функционального прогноза исхода острого периода МИСИ: относительная спектральная мощность ритмов $\delta$-диапазона интактного полушария, лобно-затылочный градиент ритмов $\alpha$-диапазона пораженного полушария и межполушарная асимметрия ритмов а-диапазона.

\section{Introduction}

Cerebral ischemic supratentorial stroke (CISS) as the most common form of cerebrovascular pathology is a global problem of modern times. Its special medical and social significance is due to the leading positions in the structure of death and disability causes in most countries of the world [1-3]. One of the most appropriate means to improve the effectiveness of treatment activities in patients with CISS is a differentiated approach development for the optimal tactics selection on the basis of an individual prognosis [4-5].

All of the mentioned above justifies the necessity of brain damage severity objectification at the onset of CISS. Electroencephalography (EEG) is one of the most informative methods to study the brain functional state. This method is highly sensitive to changes in brain bioelectrical activity that are induced by acute focal ischemia [6-8]. In combination with a millisecond time resolution, that is impossible to be used in diffusion-mediated magnetic resonance imaging and positron emission tomography [9], it explains the fact that EEG has been used for more than 40 years for cerebral ischemia detection during carotid surgery [10]. Additional advantages of the method are: noninvasiveness and absence of contraindications. Quantitative (spectral) analysis of EEG pattern allows increasing the diagnostic informative value of the method [11-14]. At the same time, the unified criteria for the determination of the short-term functional prognosis of CISS acute period outcome, which take into consideration the results of spectral analysis of the brain spontaneous bioelectrical activity, are currently absent, and the purpose of this study was to determine the most informative parameters of spectral analysis of the electroencephalographic pattern for the functional outcome of cerebral ischemic supratentorial stroke acute period prediction.

Prospective, cohort and comparative study was conducted among 103 patients in CISS acute period (61 men and 42 women, mean age was $67.7 \pm 0.8$ years), who were hospitalized within the first 24 hours from the onset of the disease and who did not undergo thrombolytic therapy.

CISS pathogenic subtype was determined in accordance with the Trial of Org 10172 in Acute Stroke Treatment (TOAST) criteria [15]. Clinical and neurological study included the neurological deficit level assessment using National Institute of Health Stroke Scale (NIHSS) in acute period dynamics. The visualization of cerebral structures was made with the help of CT scanner "Siemens Somatom Spirit" (Germany). The lesion size and the displacement of brain median structures were assessed.

The study excluded patients with acute cerebral circulation disorders, craniocerebral injury and epileptic seizures in the anamnesis, combined with the cerebral hemorrhage, hemorrhagic transformation of brain infarction, oncologic and/or decompensated somatic pathology.

Electroencephalographic study was conducted on the $2^{\text {nd }}-3^{\text {rd }}$ day of the disease with the use of 19-channel

\section{Materials and methods}

Кнючевые слова: инфаркт мозга, электроэнцефалография, прогноз. медицинский журнал. - 2018. T. 20, № 3(108). C. 324-329 
Table 1. Relative spectral rhythm power, fronto-occipital rhythm gradient and interhemispheric asymmetry values in patients with CISS on the $2^{\text {nd }}-3^{\text {rd }}$ day of the disease, $\mathrm{Me}(\mathrm{IQR})$

\begin{tabular}{lll}
\hline Indexes & Affected hemisphere & Intact hemisphere \\
\hline RSRP of delta band, $\%$ & $18.0(10.1 ; 34.9)$ & $17.3(10.2 ; 26.3)$ \\
\hline RSRP of theta1 band, $\%$ & $10.7(7.2 ; 14.4)$ & $9.7(6.6 ; 12.7)$ \\
\hline RSRP of theta2 band, $\%$ & $12.6(8.2 ; 17.5)$ & $11.6(8.0 ; 19.2)$ \\
\hline RSRP of theta band, $\%$ & $24.4(18.1 ; 30.6)$ & $21.9(16.9 ; 32.3)$ \\
\hline RSRP of alpha1 band, $\%$ & $16.8(9.9 ; 25.2)$ & $18.1(12.5 ; 28.0)$ \\
\hline RSRP of alpha2 band, $\%$ & $8.3(5.4 ; 13.2)$ & $9.5(6.3 ; 15.6)$ \\
\hline RSRP of alpha band, $\%$ & $27.2(17.0 ; 41.6)$ & $31.7(22.5 ; 43.2)$ \\
\hline RSRP of beta1 band, $\%$ & $14.5(8.8 ; 22.1)$ & $14.8(9.1 ; 22.8)$ \\
\hline RSRP of beta2 band, $\%$ & $3.5(1.9 ; 6.3)$ & $3.2(1.7 ; 5.4)$ \\
\hline RSRP of beta band, $\%$ & $18.6(10.9 ; 29.0)$ & $18.6(11.8 ; 28.6)$ \\
\hline FORG of delta band & $0.053(-0.152 ; 0.192)$ & $0.047(-0.091 ; 0.171)$ \\
\hline FORG of theta1 band & $0.135(-0.055 ; 0.296)$ & $0.112(-0.022 ; 0.228)$ \\
\hline FORG of theta2 band & $0.040(-0.122 ; 0.258)$ & $0.064(-0.125 ; 0.205)$ \\
\hline FORG of theta band & $0.054(-0.085 ; 0.240)$ & $0.061(-0.057 ; 0.187)$ \\
\hline FORG of alpha1 band & $-0.092(-0.328 ; 0.147)$ & $-0.163(-0.366 ; 0.010)$ \\
\hline FORG of alpha2 band & $-0.038(-0.229 ; 0.130)$ & $-0.201(-0.359 ; 0.020)$ \\
\hline FORG of alpha band & $-0.099(-0.283 ; 0.097)$ & $-0.203(-0.396 ;-0.024)$ \\
\hline FORG of beta1 band & $0.103(0.001 ; 0.283)$ & $0.072(-0.031 ; 0.175)$ \\
\hline FORG of beta2 band & $0.247(0.066 ; 0.440)$ & $0.170(-0.021 ; 0.371)$ \\
\hline FORG of beta band & $0.144(0.037 ; 0.314)$ & $0.103(-0.014 ; 0.217)$ \\
\hline IHRA of delta band & $0.084(-0.056 ; 0.219)$ & \\
\hline IHRA of theta1 band & $0.092(-0.043 ; 0.209)$ & \\
\hline IHRA of theta2 band & $0.055(-0.090 ; 0.196)$ & \\
\hline IHRA of theta band & $0.065(-0.041 ; 0.189)$ & \\
\hline IHRA of alpha1 band & $-0.026(-0.164 ; 0.123)$ & \\
\hline IHRA of alpha2 band & $-0.033(-0.184 ; 0.081)$ & \\
\hline IHRA of alpha band & $-0.040(-0.171 ; 0.102)$ & \\
\hline IHRA of beta1 band & $0.001(-0.069 ; 0.106)$ & \\
\hline IHRA of beta2 band & $0.050(-0.048 ; 0.206)$ & \\
\hline IHRA of beta band & $0.032(-0.070 ; 0.109)$ & \\
\hline
\end{tabular}

Table 2. The analysis of EEG pattern rhythm structure (\%) in patients with CISS on the $2^{\text {nd }}-3^{\text {rd }}$ day of the disease versus the acute period outcome of the disease, Me (IQR)

\begin{tabular}{|l|l|l|l|}
\hline Indexes & $\begin{array}{l}\text { Unfavourable } \\
\text { functional outcome } \\
(\mathbf{n}=46)\end{array}$ & $\begin{array}{l}\text { Favourable } \\
\text { functional outcome } \\
(\mathbf{n}=57)\end{array}$ & $\mathbf{P}$ \\
\hline RSRP of delta band AH & $37.9(30.3 ; 43.4)$ & $10.1(7.5 ; 14.7)$ & $<0.0001$ \\
\hline RSRP of theta1 band AH & $11.4(8.7 ; 16.3)$ & $8.9(6.4 ; 13.8)$ & 0.0226 \\
\hline RSRP of theta2 band AH & $13.5(8.7 ; 17.6)$ & $11.2(7.4 ; 14.2)$ & 0.2706 \\
\hline RSRP of theta band AH & $24.9(22.4 ; 34.1)$ & $21.9(15.1 ; 26.7)$ & 0.0196 \\
\hline RSRP of alpha1 band AH & $10.3(8.2 ; 15.5)$ & $22.3(17.2 ; 31.6)$ & $<0.0001$ \\
\hline RSRP of alpha2 band AH & $5.7(4.5 ; 8.7)$ & $13.6(8.3 ; 18.0)$ & $<0.0001$ \\
\hline RSRP of alpha band AH & $17.3(12.4 ; 24.3)$ & $40.8(29.9 ; 47.4)$ & $<0.0001$ \\
\hline RSRP of beta1 band AH & $11.0(6.4 ; 16.6)$ & $20.8(14.4 ; 26.8)$ & $<0.0001$ \\
\hline RSRP of beta2 band AH & $2.3(1.1 ; 5.7)$ & $3.9(2.2 ; 8.3)$ & 0.0068 \\
\hline RSRP of beta band AH & $13.6(7.7 ; 22.4)$ & $25.5(17.9 ; 33.8)$ & $<0.0001$ \\
\hline RSRP of delta band IH & $28.4(22.1 ; 39.8)$ & $9.5(7.1 ; 13.1)$ & $<0.0001$ \\
\hline RSRP of theta1 band IH & $10.0(6.8 ; 13.9)$ & $8.5(6.1 ; 11.6)$ & 0.1201 \\
\hline RSRP of theta2 band IH & $13.5(9.7 ; 20.0)$ & $10.1(7.7 ; 14.2)$ & 0.0727 \\
\hline RSRP of theta band IH & $25.1(19.4 ; 36.2)$ & $19.3(15.8 ; 24.0)$ & 0.0203 \\
\hline RSRP of alpha1 band IH & $14.7(10.1 ; 21.2)$ & $21.5(16.4 ; 31.0)$ & 0.0029 \\
\hline RSRP of alpha2 band IH & $8.0(5.7 ; 12.7)$ & $14.9(9.4 ; 23.0)$ & 0.0005 \\
\hline RSRP of alpha band IH & $24.9(17.3 ; 32.0)$ & $40.3(31.9 ; 52.5)$ & $<0.0001$ \\
\hline RSRP of beta1 band IH & $10.9(7.6 ; 15.6)$ & $19.2(13.8 ; 27.1)$ & $<0.0001$ \\
\hline RSRP of beta2 band IH & $2.0(1.3 ; 3.7)$ & $4.2(2.5 ; 6.4)$ & 0.0002 \\
\hline RSRP of beta band IH & $13.7(8.9 ; 18.5)$ & $24.2(17.2 ; 32.8)$ & $<0.0001$ \\
\hline
\end{tabular}

electroencephalographic scanner "NeuroCom Standard" (XAI-Medica, Ukraine). Electrodes were placed in accordance with the international system "10-20". The oculographic, rheographic and electrocardiographic artifacts were rejected with the use of software tools and the Independent Component Analysis (Blind Sourse Separation Technology) procedure. The 60-second epochs after artifact rejection were selected for the spectral analysis. The spectral analysis was carried out with the help of fast Fourier transform method. The values of absolute spectral rhythm power of delta $(0.5-4 \mathrm{~Hz})$, theta $(4-8 \mathrm{~Hz})$, alpha (8$13 \mathrm{~Hz})$, beta $(13-35 \mathrm{~Hz})$, theta1 $(4-6 \mathrm{~Hz})$, theta2 $(6-8 \mathrm{~Hz})$, alpha1 $(8-10 \mathrm{~Hz})$, alpha2 $(10-13 \mathrm{~Hz})$, beta1 $(13-25 \mathrm{~Hz})$ and beta2 $(25-35 \mathrm{~Hz})$ bands in the affected hemisphere $(\mathrm{AH})$ and intact hemisphere $(\mathrm{IH})$ were determined. The relative spectral rhythm power (RSRP) values of the specified frequency bands (\%) were calculated. To quantify the zonal differences of the rhythm distribution within $\mathrm{AH}$ and $\mathrm{IH}$, the values of the fronto-occipital rhythm gradient (FORG) were calculated using the following formula: $F O R G=(A S R P$ in the frontal region - ASRP in the occipital region) / (ASRP in the frontal region + ASRP in the occipital region). The severity of interhemispheric rhythm asymmetry (IHRA) was determined on the basis of the following formula: IHRA = (ASRP in the AH - ASRP in the IH) / (ASRP in the $A H+A S R P$ in the $I H)$.

All patients received standard therapy in accordance with the Unified Clinical Protocol for medical care "Ischemic stroke (urgent, primary and secondary (specialized) medical care, medical rehabilitation)", approved by the order of the Ministry of Health of Ukraine №604 of August 03, 2012. The functional outcome of the disease acute period was assessed on the 21st day on the basis of the modified Rankin Scale (mRS), while the value of $\mathrm{mRS}$ score $>3$ was considered as an unfavourable functional outcome, whereas mRS score $\leq 3$ was considered as a favourable one.

Statistical analysis of the results was carried out using the software Statistica 6.0 (StatSoft Inc., USA, series number AXXR712D833214FAN5) and MedCalc (version 16.4). The distribution normality of the studied traits was estimated in accordance with the Shapiro-Wilk criterion. Descriptive statistics are presented in the form of $\mathrm{M} \pm \mathrm{m}$ for values with normal distribution and in the form of median (Me) and interquartile range (IQR) for parameters with nonnormal distribution. To determine the intergroup differences in the studied characteristics, the Mann-Whitney criterion was used. Factors that had significant predictive value in the univariate logistic regression analysis were step by step included in the multivariate model in order to determine independent predictors. The cut-off points for independent predictors with the optimum sensitivity (Se) and specificity (Sp) were determined on the basis of the ROC analysis. Statistical significance of results was defined as a $P$ value $<0.05$.

\section{Results of the study}

Patients with brain infraction in the left hemisphere dominated in the studied cohort $(62.1 \%)$. Cerebral ischemic supratentorial stroke etiologic factors structure in accordance with TOAST classification was presented as follows: largeartery atherosclerosis (47.6\%), cardioembolism (18.4\%), 
small-vessel occlusion (20.4\%) and stroke of undetermined etiology (13.8\%).

The total value in accordance with NIHSS score and infarct volume on admission constituted 9.0 (7.0; 14.0) and $20.6(6.0 ; 59.2) \mathrm{mL}$, respectively, septum pellucidum displacement and pineal gland displacement were detected in $8(7.8 \%)$ patients.

The results of EEG pattern spectral analysis in patients with CISS on the $2^{\text {nd }}-3^{\text {rd }}$ day of the disease are shown in Table 1 and Table 2.

Unfavourable functional outcome (mRS score $>3$ on the $21^{\text {st }}$ day of the disease) was detected in 46 (44.6\%) patients. Patients with an unfavourable functional CISS acute period outcome at onset of the disease has a higher severity of neurologic deficit in accordance with the NIHSS $(14,5(10,3 ; 16,0)$ versus $7,0(6,0 ; 9,0), P<0.0001)$ and a larger infarct volume $(45,4(15,7 ; 93,0) \mathrm{mL}$ versus $11,4(4,0$; $37,1) \mathrm{mL}, \mathrm{P}=0.0006$ ).

The analysis of EEG pattern rhythm structure (\%) was made in patients with CISS on the $2^{\text {nd }}-3^{\text {rd }}$ day of the disease versus the acute period outcome of the disease (Table 2).

The presented data shows that patients with an unfavourable functional outcome of CISS acute period had higher RSRP of delta band on the $2^{\text {nd }}-3^{\text {rd }}$ day of the disease (37.9 (30.3; 43.4) \% versus $10.1(7.5 ; 14.7) \%$ in the $\mathrm{AH}$; $28.4(22.1 ; 39.8) \%$ versus $9.5(7.1 ; 13.1) \%$ in the $\mathrm{IH}$, $\mathrm{P}<0.0001$ for both values) and RSRP of theta band ( 24.9 $(22.4 ; 34.1) \%$ versus $21.9(15.1 ; 26.7) \%$ in the $\mathrm{AH} ; 25.1$ $(19.4 ; 36.2) \%$ versus $19.3(15.8 ; 24.0) \%$ in the $\mathrm{IH}, \mathrm{P}<0.05$ for both values) along with lower RSRP of alpha band (17.3 $(12.4 ; 24.3) \%$ versus $40.8(29.9 ; 47.4) \%$ in the $\mathrm{AH}$; $24.9(17.3 ; 32.0)$ \% versus $40.3(31.9 ; 52.5) \%$ in the $\mathrm{IH}$, $\mathrm{P}<0.0001$ for both values) and RSRP of beta band (13.6 $(7.7 ; 22.4) \%$ versus $25.5(17.9 ; 33.8) \%$ in the $\mathrm{AH} ; 13.7$ $(8.9 ; 18.5)$ versus $24.2(17.2 ; 32.8) \%$ in the $\mathrm{IH}, \mathrm{P}<0.0001$ for both values). The revealed changes in RSRP of alpha and delta bands dominated in the $\mathrm{AH}$, whereas changes in RSRP of beta and theta bands had bilateral character. Rhythms of alpha and delta bands dominated in the EEGstructure in patients with favourable functional outcome of CISS acute period on the $2^{\text {nd }}-3^{\text {rd }}$ days of the disease.

The inversion of negative FORG of alpha, alpha1 and alpha2 bands in the $\mathrm{AH}$ was representative of patients with unfavourable functional outcome of CISS acute period, as well as a positive tendency of FORG of delta, beta, beta1 bands on the $2^{\text {nd }}-3^{\text {rd }}$ day of the disease, whereas the reduction of negative FORG of alpha2 band was detected in the intact hemisphere (Table 3).

Patients with CISS and unfavourable functional outcome on the $2^{\text {nd }}$ and $3^{\text {rd }}$ day of the disease had IHRA of alpha, alpha1 and alpha2 bands, which was proved by negative values of corresponding indexes (Table 4).

Parameters of EEG pattern spectral analysis were determined on the basis of the univariate logistic regression analysis. They were associated with the functional outcome of CISS acute period. Independent interrelation was determined only for 3 of them: RSRP of delta band in the $\mathrm{IH}$ (OR $95 \% \mathrm{Cl}=1.31(1.13-1.52), \mathrm{P}=0.0004)$, FORG of alpha band in the $\mathrm{AH}(\mathrm{OR} 95 \% \mathrm{Cl}=29.07(1.86-455.15)$, $\mathrm{P}=0.0224)$ and IHRA of alpha band $(\mathrm{OR} 95 \% \mathrm{Cl}=0.01$ (0.0001-0.80), $\mathrm{P}=0.0402$ ) (Table 5).

Cut-off points for these indexes with optimal sensitivity
Table 3. Analysis of zonal differences in the EEG-pattern of affected and intact hemispheres in patients with CISS on the $2^{\text {nd }}-3^{\text {rd }}$ day of the disease versus the functional outcome of the disease acute period, Me (IQR)

\begin{tabular}{l|l|l|l|}
\hline Indexes & $\begin{array}{l}\text { Unfavourable functional } \\
\text { outcome }(\mathbf{n}=46)\end{array}$ & $\begin{array}{l}\text { Favourable functional } \\
\text { outcome }(\mathbf{n}=57)\end{array}$ & $\mathbf{P}$ \\
\hline FORG of delta band $\mathrm{AH}$ & $0.119(-0.135 ; 0.315)$ & $0.003(-0.155 ; 0.145)$ & 0.0403 \\
\hline FORG of theta1 band AH & $0.171(-0.044 ; 0.333)$ & $0.068(-0.062 ; 0.225)$ & 0.1124 \\
\hline FORG of theta2 band AH & $0.102(-0.089 ; 0.354)$ & $0.016(-0.134 ; 0.223)$ & 0.1217 \\
\hline FORG of theta band AH & $0.187(-0.040 ; 0.307)$ & $0.023(-0.091 ; 0.214)$ & 0.0545 \\
\hline FORG of alpha1 band AH & $0.048(-0.161 ; 0.215)$ & $-0.197(-0.481 ; 0.024)$ & 0.0002 \\
\hline FORG of alpha2 band AH & $0.074(-0.140 ; 0.223)$ & $-0.126(-0.301 ; 0.003)$ & 0.0001 \\
\hline FORG of alpha band $\mathrm{AH}$ & $0.030(-0.122 ; 0.199)$ & $-0.168(-0.415 ;-0.027)$ & $<0.0001$ \\
\hline FORG of beta1 band $\mathrm{AH}$ & $0.212(0.062 ; 0.365)$ & $0.052(-0.033 ; 0.177)$ & 0.0040 \\
\hline FORG of beta2 band $\mathrm{AH}$ & $0.287(0.102 ; 0.494)$ & $0.217(0.060 ; 0.424)$ & 0.3393 \\
\hline FORG of beta band $\mathrm{AH}$ & $0.233(0.075 ; 0.375)$ & $0.071(0.021 ; 0.220)$ & 0.0096 \\
\hline FORG of delta band IH & $0.045(-0.078 ; 0.195)$ & $0.048(-0.128 ; 0.148)$ & 0.6320 \\
\hline FORG of theta1 band IH & $0.074(-0.019 ; 0.202)$ & $0.148(-0.024 ; 0.238)$ & 0.7891 \\
\hline FORG of theta2 band IH & $0.039(-0.093 ; 0.162)$ & $0.099(-0.141 ; 0.275)$ & 0.3228 \\
\hline FORG of theta band IH & $0.052(-0.047 ; 0.163)$ & $0.068(-0.064 ; 0.229)$ & 0.4733 \\
\hline FORG of alpha1 band IH & $-0.143(-0.338 ; 0.017)$ & $-0.192(-0.400 ; 0.003)$ & 0.6414 \\
\hline FORG of alpha2 band IH & $-0.080(-0.344 ; 0.106)$ & $-0.249(-0.396 ;-0.057)$ & 0.0397 \\
\hline FORG of alpha band IH & $-0.117(-0.385 ; 0.030)$ & $-0.234(-0.401 ;-0.095)$ & 0.1170 \\
\hline FORG of beta1 band IH & $0.079(-0.006 ; 0.201)$ & $0.047(-0.050 ; 0.159)$ & 0.2073 \\
\hline FORG of beta2 band IH & $0.157(-0.029 ; 0.392)$ & $0.179(-0.010 ; 0.355)$ & 0.9185 \\
\hline FORG of beta band IH & $0.122(-0.011 ; 0.250)$ & $0.073(-0.026 ; 0.170)$ & 0.3810 \\
\hline
\end{tabular}

Table 4. Intergroup analysis of IHRA differences versus acute period outcome of the disease, Me (IQR)

\begin{tabular}{l|l|l|l|}
\hline Indexes & $\begin{array}{l}\text { Unfavourable functional } \\
\text { outcome }(\mathbf{n}=46)\end{array}$ & $\begin{array}{l}\text { Favourable functional } \\
\text { outcome }(\mathbf{n}=57)\end{array}$ & $\mathbf{P}$ \\
\hline IHRA of delta band & $0.108(-0.093 ; 0.233)$ & $0.079(-0.054 ; 0.186)$ & 0.3529 \\
\hline IHRA of theta1 band & $0.124(-0.016 ; 0.212)$ & $0.082(-0.043 ; 0.205)$ & 0.2706 \\
\hline IHRA of theta2 band & $0.014(-0.092 ; 0.205)$ & $0.067(-0.060 ; 0.191)$ & 0.5721 \\
\hline IHRA of theta band & $0.059(-0.042 ; 0.203)$ & $0.065(-0.032 ; 0.175)$ & 0.8975 \\
\hline IHRA of alpha1 band & $-0.106(-0.215 ; 0.059)$ & $0.032(-0.114 ; 0.142)$ & 0.0133 \\
\hline IHRA of alpha2 band & $-0.086(-0.219 ;-0.001)$ & $0.015(-0.085 ; 0.112)$ & 0.0141 \\
\hline IHRA of alpha band & $-0.108(-0.222 ; 0.031)$ & $0.019(-0.098 ; 0.131)$ & 0.0061 \\
\hline IHRA of beta1 band & $-0.007(-0.100 ; 0.114)$ & $0.028(-0.045 ; 0.094)$ & 0.3293 \\
\hline IHRA of beta2 band & $0.090(-0.034 ; 0.224)$ & $0.038(-0.059 ; 0.175)$ & 0.2537 \\
\hline IHRA of beta band & $0.016(-0.095 ; 0.121)$ & $0.038(-0.039 ; 0.105)$ & 0.5676 \\
\hline IHRA total & $0.036(-0.050 ; 0.158)$ & $0.052(-0.075 ; 0.112)$ & 0.5454 \\
\hline
\end{tabular}

and specificity interrelation were determined on the basis of the ROC-analysis for functional outcome of the disease acute period prognosis: RSRP of delta band in $\mathrm{IH}>18.4 \%$ (Se $=87.0 \%$, Sp $=87.7 \%$; AUC $95 \% \mathrm{Cl}=0.94(0.87-0.98)$, $\mathrm{P}<0.0001)$, FORG of alpha band in the $\mathrm{AH}>-0.066$ $(\mathrm{Se}=67.4 \%, \mathrm{Sp}=70.0 \%$; AUC $95 \% \mathrm{Cl}=0.74(0.65-0.82)$, $\mathrm{P}<0.0001)$ and IHRA of alpha band $\leq-0.066$ ( $\mathrm{Se}=60.9 \%$, $\mathrm{Sp}=70.2 \%$; AUC $95 \% \mathrm{Cl}=0.66(0.56-0.75), \mathrm{P}<0.0039)$.

The frequency distribution of unfavourable functional outcome of the CISS acute period in terms of RSRP of delta band in the $\mathrm{IH}, \mathrm{FORG}$ of alpha band in the $\mathrm{AH}$ and IHRA of alpha band is shown in Table 6 .

As a result, the RSRP of delta band in the $\mathrm{HH}>18.4 \%$, FORG of alpha band in the AH >-0.066 and IHRA of alpha band $(\mathrm{Se}=60.9 \%, \mathrm{Sp}=70.2 \%$ AUC $95 \% \mathrm{Cl}=0.66$ (0.56-0.75), $\mathrm{P}<0.0039)$ were associated with increased risk of the unfavourable outcome of CISS acute period 7.0 fold (95 \% Cl 3.7-17.1, P < 0.0001), 2.4 (95\% Cl 1.5-3.8, $\mathrm{P}=0.0004)$ and $2.0-$ fold $(95 \% \mathrm{Cl} 1.3-3.1, \mathrm{P}=0.0022)$, respectively. 
Table 5. Dependent and independent predictors of CISS acute period unfavourable functional outcome (univariate and multivariate models)

\begin{tabular}{|c|c|c|c|c|}
\hline \multirow[t]{2}{*}{ Indexes } & \multicolumn{2}{|c|}{$\begin{array}{l}\text { Univariate logistic regression } \\
\text { model }\end{array}$} & \multicolumn{2}{|l|}{$\begin{array}{l}\text { Multivariate logistic } \\
\text { regression model } \\
\end{array}$} \\
\hline & OR (95\% Cl) & $\mathbf{P}$ & OR (95 \% CI) & $\mathbf{P}$ \\
\hline Admission NIHSS score & $1.65(1.37-1.98)$ & $<0.0001$ & $1.61(1.15-2.24)$ & 0.0050 \\
\hline Infarct volume & $1.02(1.00-1.03)$ & 0.0056 & & \\
\hline RSRP of delta band $\mathrm{AH}$ & $1.20(1.13-1.28)$ & $<0.0001$ & & \\
\hline RSRP of theta 1 band $\mathrm{AH}$ & $1.08(1.00-1.15)$ & 0.0231 & & \\
\hline RSRP of alpha1 band $\mathrm{AH}$ & $0.89(0.84-0.94)$ & $<0.0001$ & & \\
\hline RSRP of alpha2 band $\mathrm{AH}$ & $0.78(0.70-0.88)$ & $<0.0001$ & & \\
\hline RSRP of alpha band $\mathrm{AH}$ & $0.89(0.85-0.93)$ & $<0.0001$ & & \\
\hline RSRP of beta 1 band $\mathrm{AH}$ & $0.90(0.85-0.95)$ & 0.0002 & & \\
\hline RSRP of beta2 band $\mathrm{AH}$ & $0.87(0.77-0.99)$ & 0.0337 & & \\
\hline RSRP of beta band $\mathrm{AH}$ & $0.93(0.89-0.97)$ & 0.0001 & & \\
\hline RSRP of delta band IH & $1.35(1.21-1.52)$ & $<0.0001$ & $1.31(1.13-1.52)$ & 0.0004 \\
\hline RSRP of alpha1 band IH & $0.95(0.92-0.99)$ & 0.0091 & & \\
\hline RSRP of alpha2 band IH & $0.89(0.83-0.96)$ & 0.0011 & & \\
\hline RSRP of alpha band IH & $0.93(0.91-0.97)$ & 0.0001 & & \\
\hline RSRP of beta 1 band IH & $0.90(0.85-0.95)$ & 0.0002 & & \\
\hline RSRP of beta2 band IH & $0.77(0.67-0.91)$ & 0.0026 & & \\
\hline RSRP of beta band IH & $0.93(0.88-0.96)$ & 0.0002 & & \\
\hline FORG of alpha1 band $\mathrm{AH}$ & $15.36(3.39-69.56)$ & 0.0004 & & \\
\hline FORG of alpha2 band $\mathrm{AH}$ & $34.52(4.86-245.31)$ & 0.0004 & & \\
\hline FORG of alpha band $\mathrm{AH}$ & 34.91 (5.81-209.92) & 0.0001 & $29.07(1.86-455.15)$ & 0.0224 \\
\hline FORG of beta1 band $\mathrm{AH}$ & $9.23(1.46-58.17)$ & 0.0180 & & \\
\hline FORG of alpha2 band IH & $5.13(1.08-24.42)$ & 0.0355 & & \\
\hline IHRA of alpha1 band & $0.08(0.01-0.54)$ & 0.0100 & & \\
\hline IHRA of alpha2 band & $0.09(0.01-0.81)$ & 0.0319 & & \\
\hline IHRA of alpha band & $0.05(0.01-0.43)$ & 0.0067 & $0.01(0.0001-0.80)$ & 0.0402 \\
\hline
\end{tabular}

Table 6. Frequency distribution of unfavourable functional outcome of the CISS acute period in terms of RSRP of delta band in the IH, FORG of alpha band in the AH and IHRA of alpha band

\begin{tabular}{l|l|l|l|} 
Parameters & Value & $\begin{array}{l}\text { Number } \\
\text { of patients }\end{array}$ & $\begin{array}{l}\text { Unfavourable functional outcome } \\
\text { of the CISS acute period (\%) }\end{array}$ \\
\hline RSRP of delta band in IH, \% & $>18.4$ & 47 & 85.1 \\
& $\leq 18.4$ & 56 & 10.7 \\
\hline FORG of alpha-range in AH & $>-0.066$ & 48 & 64.6 \\
& $\leq-0.066$ & 55 & 27.2 \\
\hline IHRA of alpha band & $\leq-0.066$ & 45 & 62.2 \\
& $>-0.066$ & 58 & 31.0 \\
\hline
\end{tabular}

\section{Discussion}

Thus, on the basis of the EEG patterns spectral analysis comparative analysis it was determined that patients with the unfavourable outcome of CISS acute period on the $2^{\text {nd }}$ $3^{\text {rd }}$ day of the disease had a higher severity of bioelectric brain activity impairment in affected and intact hemispheres. This cohort of patients had higher values of RSRP of delta and theta bands and lower levels of RSRP of alpha and beta bands, whereas the increase in demonstrated changes severity was in the affected hemisphere. In addition, patients with the unfavourable outcome of CISS acute period on the $2^{\text {nd }}-3^{\text {rd }}$ day of the disease had ipsilateral reduction of zonal rhythm differences of alpha, alpha1 and alpha2 bands, which was due to a more severe depression of the absolute spectral power of the specified rhythms in caudal parts of the affected hemisphere. It was accompanied by the generation of interhemispheric asymmetry of absolute spectral rhythm power of alpha band and complied with the results of other studies.

Thus, in accordance with S. P. Finnigan et al. (2007) sub-acute delta/alpha power ratio $(R=0.91, P<0.001)$ and relative alpha power $(R=-0.82, P<0.01)$ were significantly correlated with 30-day NIHSS score [16]. The study of R. V. Sheorajpanday et al. (2011) determined that the EEG pairwise derived Brain Symmetry Index (pdBSI) was significantly correlated with the modified Rankin Scale (mRS) score at month $6(R=0.46, P<0.0005)$ [17]. In accordance with the data of X. Xin et al. (2017) poor functional outcomes were associated with higher BSI [18]. Our research studied the prognostic value of interhemispheric different frequency bands asymmetry indexes, while independent association with the functional outcome of CISS acute period was only determined for IHRA of alpha band. The prognostic value of FORG of alpha band in the $\mathrm{AH}$ on the $2^{\text {nd }}-3^{\text {rd }}$ day of CISS was proved, which confirms the advisability to define not only IHRA of alpha band, but also alpha-rhythm zonal differences in order to prognosticate the functional outcome of the disease acute period.

It should be noted, that the results of our study revealed the presence of RSRP delta-range of $\mathrm{IH}$ in the spectral of independent predictors of the unfavourable functional outcome of CISS acute period. It was also determined that this index has a higher informative value than IHRA of alpha band and the FORG of alpha band in the AH for the determination of a short-term functional prognosis. The obtained data complies with the results of other studies. Thus, in the study of G. Assenza et al. (2013), an increase in contralesional delta band power was mediated by interhemispheric disconnection providing negative prognosis in acute stroke [19]. In accordance with M. E. Wolf et al. (2017), generalized (but not focal) slowing were associated with clinical deterioration [20]. Thus, the intact hemisphere dysfunctional severity is also associated with the functional outcome of CISS acute period.

We determined the following cut-off points for the values of these indexes with the optimal sensitivity and specificity level for the functional outcome of CISS acute period prognosis: RSRP of delta band in the $\mathrm{IH}>18.4 \%$ ( $\mathrm{Se}=87.0 \%, \mathrm{Sp}=87.7 \%$ ), FORG of alpha band in the $\mathrm{AH}>-0.066(\mathrm{Se}=67.4 \%, \mathrm{Sp}=70.0 \%)$ and IHRA of alpha band $\leq-0.066$ ( $\mathrm{Se}=60.9 \%, \mathrm{Sp}=70.2 \%$ ). It is advisable to use the obtained criteria for the determination of a short-term functional prognosis as the basis for the optimization of therapy measures applied to patients with CISS.

\section{Conclusions}

1. The following are the parameters which had the highest informative value as for EEG pattern spectral analysis on the $2^{\text {nd }}-3^{\text {rd }}$ day of CISS and which have an independent association with the functional outcome of the disease acute period: RSRP of delta band in the $\mathrm{IH}(\mathrm{OR} 95 \% \mathrm{Cl}=1.31$ (1.13-1.52), $\mathrm{P}=0.0004), \mathrm{FORG}$ of alpha band in the $\mathrm{AH}(\mathrm{OR}$ $95 \% \mathrm{Cl}=29.07(1.86-455.15), \mathrm{P}=0.0224)$ and IHRA of alpha band (OR $95 \% \mathrm{Cl}=0.01(0.0001-0.80), \mathrm{P}=0.0402)$.

2. Predictors of the unfavourable functional outcome of CISS acute period were the RSRP of delta band in the $\mathrm{IH}>18.4 \%(\mathrm{Se}=87.0 \%$, Sp $=87.7 \%$; AUC $95 \%$ 
$\mathrm{Cl}=0.94(0.87-0.98), \mathrm{P}<0.0001 ; \mathrm{RR}(95 \% \mathrm{Cl})=7.0$ (3.717.1), $\mathrm{P}<0.0001)$, FORG of alpha band in the $\mathrm{AH}>-0.066$ $(\mathrm{Se}=67.4 \%, \mathrm{Sp}=70.0 \%$; AUC $95 \% \mathrm{Cl}=0.74(0.65-0.82)$, $\mathrm{P}<0.0001 ; \operatorname{RR}(95 \% \mathrm{Cl})=2.4(1.5-3.8), \mathrm{P}=0.0004)$ and IHRA of alpha band $\leq-0.066(\mathrm{Se}=60.9 \%, \mathrm{Sp}=70.2 \%$; AUC $95 \% \mathrm{Cl}=0.66(0.56-0.75), \mathrm{P}<0.0039$; RR (95\% $C I)=2.0(1.3-3.1), P=0.0022)$ on the $2^{\text {nd }}-3^{\text {rd }}$ day of the disease.

The perspective for the further scientific research is the criteria of the unfavourable vital outcome of CISS acute period elaboration on the basis of EEG pattern spectral analysis.

Фінансування: АосліАження виконане в рамках НАР Запорізького державного медичного університету “Оптимізація Аіагностичних та мікувально-реабілітаційних заходів у хворих з гострими і хронічними порушеннями мозкового кровообігу" № Аержреєстрації $0113 \cup 000798$ (2013-2017).

Conflicts of Interest: author has no conflict of interest to declare. Конфлікт інтересів: віАсутній.

Information about author:

Kuznietsov A. A., MD, PhD, Associate Professor of the Department of Nervous Diseases, Zaporizhzhia State Medical University, Ukraine.

\section{Відомості про автора:}

Кузнєцов А. А., канА. меА. наук, Аоцент каф. нервових хвороб, Запорізький Аержавний медичний університет, Україна.

\section{Сведения об авторе:}

Кузнецов А. А., канА. меА. наук, Аоцент каф. нервных болезней, Запорожский государственный меАицинский университет, Украина.

Надійшла Ао редакції / Received: 24.04.2018

Після Аоопрацювання / Revised: 04.05.2018

Прийнято Ао Аруку / Accepted: 08.05.2018

\section{References}

[1] Ministerstvo okhorony zdorovia Ukrainy (2012). Unifikovanyi klinichnyi protokol medychnoi dopomohy «lshemichnyi insult (ekstrena, pervynna, vtorynna (spetsializovana) medychna dopomoha, medychna reabilitatsiia)» [Unified clinical protocol for medical aid «Ischemic stroke (emergency, primary, secondary (specialized) medical aid, medical rehabilitation)»]. Retrieved from http://mtd.dec.gov.ua/images/dodatki/2012_602/2012_602dod4ykpmd.pdf.

[2] Ovbiagele, B., Goldstein, L. B., Higashida, R. T., Howard, V. J., Johnston, S. C., Khavjou, O. A., et al. (2013). Forecasting the future of stroke in the United States: a policy statement from the American Heart Association and American Stroke Association. Stroke, 44(8), 2361-2375. doi: 10.1161/STR.0b013e31829734f2.

[3] Pearson, T. A., Palaniappan, L. P., Artinian, N. T., Carnethon, M. R., Criqui, M. H., Daniels, S. R., et al. (2013). American Heart Association Guide for Improving Cardiovascular Health at the Community Level, 2013 update: a scientific statement for public health practitioners, healthcare providers, and health policy makers. Circulation, 127(16), 1730-1753. doi: 10.1161/CIR.0b013e31828f8a94.

[4] Esteghamati, A., Hafezi-Nejad, N., Sheikhbahaei, S., Heidari, B., Zandieh, A., \& Eslami, V. (2014). Comparing the Predictive Ability of Prognostic Models in Ischemic Stroke; Derivation, Validation, and Discrimination Beyond the ROC Curve. Front Neurol, 5, 9. doi: 10.3389/ fneur.2014.00009

[5] Fahey, M., Crayton, E., Wolfe, C., \& Douiri, A. (2018). Clinical prediction models for mortality and functional outcome following ischemic stroke: A systematic review and meta-analysis. PLoS One, 13(1), e0185402. doi: 10.1371/journal.pone.0185402.

[6] Diedler, J., Sykora., M., Bast, T., Poli, S., Veltkamp, R., Mellado, P., et al. (2009). Quantitative EEG correlates of low cerebral perfusion in severe stroke. Neurocrit Care, 11(2), 210-216. doi: 10.1007/s12028009-9236-6.

[7] Jordan, K. G. (2004). Emergency EEG and continuous EEG monitoring in acute ischemic stroke. J Clin Neurophysiol, 21(5), 341-352.

[8] van Putten, M. J., \& Hofmeijer, J. (2016). EEG Monitoring in Cerebral Ischemia: Basic Concepts and Clinical Applications. J Clin Neurophysiol, 33(3), 203-210. doi: 10.1097/WNP.0000000000000272.

[9] Finnigan, S. P., Rose, S. E., Walsh, M., Griffin, M., Janke, A. L. McMahon, K. L., et al. (2004). Correlation of quantitative EEG in acute ischemic stroke with 30-day NIHSS score: comparison with diffusion and perfusion MRI. Stroke, 35(4), 899-903. doi: 10.1161/01. STR.0000122622.73916.d2.

[10] Li, J., Shalabi,A., Ji, F., \& Meng, L. (2016). Monitoring cerebral ischemia during carotid endarterectomy and stenting. J Biomed Res, 31(1), 11-16. doi: 10.7555/JBR.31.20150171.

[11] Cuspineda, E., Machado, C., Galán, L., Aubert, E., Alvarez, M. A., Llopis, F., et al. (2007). QEEG prognostic value in acute stroke. Clin EEG Neurosci, 38(3), 155-160. doi: 10.1177/155005940703800312.

[12] Sheorajpanday, R. V., Nagels, G., Weeren, A. J., van Putten, M. J., \& De Deyn, P. P. (2009). Reproducibility and clinical relevance of quantitative EEG parameters in cerebral ischemia: a basic approach. Clin Neurophysiol, 120(5), 845-855. doi: 10.1016/j.clinph.2009.02.171.

[13] Sheorajpanday, R. V., Nagels, G., Weeren, A. J., De Surgeloose, D., \& De Deyn, P. P. (2010). Additional value of quantitative EEG in acute anterior circulation syndrome of presumed ischemic origin. Clin Neurophysiol, 121(10), 1719-1725. doi: 10.1016/j.clinph.2009.10.037.

[14] Wu, J., Srinivasan, R., Burke Quinlan, E., Solodkin, A., Small, S. L., \& Cramer, S. C. (2016). Utility of EEG measures of brain function in patients with acute stroke. J Neurophysiol, 115(5), 2399-2405. doi: 10.1152/jn.00978.2015.

[15] Adams, H. P. Jr., Bendixen, B. H., Kappelle, L. J., Biller, J., Love, B. B. Gordon, D. L., \& Marsh, E. E. 3rd. (1993). Classification of subtype of acute ischemic stroke. Definitions for use in a multicenter clinical trial. TOAST. Trial of Org 10172 in Acute Stroke Treatment. Stroke, 24(1), 35-41.

[16] Finnigan, S. P., Walsh, M., Rose, S. E., \& Chalk, J. B. (2007). Quantitative EEG indices of sub-acute ischaemic stroke correlate with clinical outcomes. Clin Neurophysiol, 118(11), 2525-2532. doi: 10.1016/j. clinph.2007.07.021.

[17] Sheorajpanday, R. V., Nagels, G., Weeren, A. J., van Putten, M. J., \& De Deyn, P. P. (2011). Quantitative EEG in ischemic stroke: correlation with functional status after 6 months. Clin Neurophysiol, 122(5), 874-883. doi: 10.1016/j.clinph.2010.07.028

[18] Xin, X., Chang, J., Gao, Y., \& Shi, Y. (2017). Correlation Between the Revised Brain Symmetry Index, an EEG Feature Index, and Shortterm Prognosis in Acute Ischemic Stroke. J Clin Neurophysiol, 34(2), 162-167. doi: 10.1097/WNP.0000000000000341.

[19] Assenza, G., Zappasodi, F., Pasqualetti, P., Vernieri, F., \& Tecchio, F. (2013). A contralesional EEG power increase mediated by interhemispheric disconnection provides negative prognosis in acute stroke. Restor Neurol Neurosci, 31(2), 177-188. doi: 10.3233/RNN-120244.

[20] Wolf, M. E., Ebert, A. D., \& Chatzikonstantinou, A. (2017). The use of routine EEG in acute ischemic stroke patients without seizures: generalized but not focal EEG pathology is associated with clinical deterioration. Int J Neurosci, 127(5), 421-426. doi: 10.1080/002074 54.2016.1189913. 